Demitra Januar Bawole, Hanna Prillysca Chernovita

\title{
Algoritma Bellman-Ford untuk Menentukan Jalur Terpendek dalam Survey Klaim Asuransi \\ (Studi Kasus : PT. Asuransi Sinar Mas, Jakarta)
}

\author{
Demitra Januar Bawole \\ Universitas Kristen Satya Wacana \\ Hanna Prillysca Chernovita, S.SI., M.Cs. \\ Universitas Kristen Satya Wacana \\ demitrabawole23@gmail.com \\ hanna.chernovita@uksw.edu
}

\begin{abstract}
Abstrak
Dalam dunia asuransi kepercayaan tertanggung terhadap asuransi merupakan kunci suksesnya asuransi. Kepercayaan tertanggung dalam hal service klaim yang berdasar dari speed (kecepatan) dan fairness (keadilan) dinilai berdasarkan penanganan cepat terhadap klaim dan keadilan klaim antara tertanggung (customer) serta penanggung (asuransi). Dalam meningkatkan kepercayaan tertanggung dibutuhkan efisiensi dari segi waktu proses klaim. Penelitian ini menerapkan perhitungan menggunakan Algoritma Bellman-Ford yang bertujuan untuk mencari jalur terpendek dengan mengambil contoh kasus dari kantor pusat PT. Asuransi Sinar Mas menuju Auto 2000 Daan Mogot dan menghasilkan rute terpendek sepanjan Algoritma Bellman-Ford digunakan untuk menghitung semua jalur dari tempat asal ke tempat tujuan yang terbentuk dalam sebuah graf agar ditemukan jalur terpendek.
\end{abstract}

Kata Kunci: Asuransi, Klaim, Algoritma Bellman-Ford, Rute

\section{Pendahuluan}

Asuransi atau Pertanggungan adalah perjanjian, dimana penanggung mengikatkan diri terhadap tertanggung dengan memperoleh premi, untuk memberikan kepadanya ganti rugi karena kehilangan, kerusakan, atau tidak mendapat keuntungan yang diharapkan, yang mungkin akan dapat diderita karena suatu peristiwa yang tidak pasti. PT. Asuransi Sinar Mas (ASM) merupakan salah satu perusahaan yang memiliki produk yaitu Simas Mobil (MBU) yang mana pihak asuransi memberikan jaminan rugi atau biaya perbaikan atas kehilangan atau kerusakan sebagian maupun keseluruhan pada kendaraan akibat kejatuhan benda, perbuatan jahat, pencurian, serta perampokan, tabrakan, benturan atau kecelakan lalu lintas ke tertanggung. ASM memiliki kewajiban untuk menanggung resiko yang terjadi kepada tertanggung, sehingga pihak yang dirugikan dapat memenuhi syarat-syarat untuk melakukan proses klaim yang diatur dalam Polis Standar Kendaraan Bermotor Indonesia (PSKBI) dengan jaminan Gabungan (Comprehensive).

Tahapan prosedur klaim partial loss, tertanggung lapor klaim ke ASM terdekat dalam waktu 5 hari kalender sejak terjadi kecelakaan via telepon, email, dan datang ke kantor cabang ASM. Setelah itu Penanggung dalam hal ini surveyour melakukan survey ke lokasi tertanggung. Dalam proses perjalanan ke lokasi dibutuhkan pemilihan rute tercepat sehingga 


\section{Demitra Januar Bawole, Hanna Prillysca Chernovita}

didapatkan efisiensi waktu dengan kondisi jalan dan kendaraan yang tidak sama. Kerugian akan dialami oleh perusahaan jika waktu menuju ke lokasi survey menjadi lebih lama karena jarak menjadi lebih jauh dan kepercayaan tertanggung terhadap Asuransi Sinar Mas akan menurun. Oleh karena itu, diperlukan pengetahuan bagi pengendara untuk memilih jalur alternatif agar mendapatkan jalur tercepat untuk mencapai ke lokasi survey.

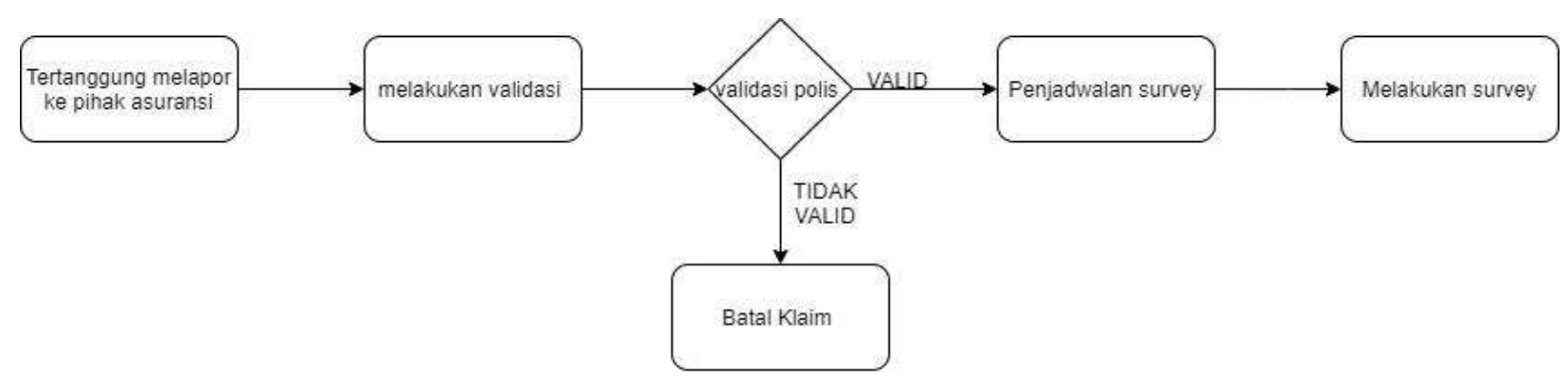

Gambar 1. Alur Survey PT. Asuransi Sinar Mas, Jakarta

Ada beberapa cara untuk mencari optimasi rute diantaranya algoritma Djiktra, algoritma Semut atau Ant Colony, algoritma Floyd Warshall, algoritma Bellman-Ford, algoritma Distance Vector, algoritma Ford-Fulkerson. Algoritma-algoritma ini dibuat untuk mencari rute yang paling efisien serta bahan bakar, dan jarak. Tujuan dari penelitian ini adalah mengetahui rute terdekat dengan pendekatan algoritma Bellman-Ford yang akan dijadikan rekomendasi surveyor atau asuransi dalam melakukan survey ke tempat tertanggung dengan jarak yang ditempuh seminimal mungkin. Dengan penelitian ini kiranya dapat bermanfaat untuk PT. Asuransi Sinar Mas pada khususnya dan Asuransi pada umumnya dalam menentukan jarak survey klaim.

\section{Landasan Teori}

Penelitian terkait jalur terpendek yang telah dilakukan dengan judul Analisis Algoritma Dijktra dan Algoritma Bellman-Ford Sebagai Penentuan Jalur Terpendek Menuju Lokasi Kebakaran (Studi Kasus: Kecamatan Praya Kota) yang ditulis oleh Saeful Hamdi, Prihandoko mengevaluasi performa menurut Russel (2011) untuk mengukur kinerja dari setiap algoritma menggunakan empat kerteria yaitu kelengkapan (Completeness), optimalisasi (optomality), kompleksitas waktu (time complexity), dan kompleksitas ruang (space complexity). Kriteria tersebut untuk menganalisis performa dari algoritma untuk menghasilkan solusi yang dapat disimpulkan bahwa Algoritma Dijktra dan Algoritma Bellman-Ford sebagai penentuan jalur terpendek. Adapun perbedaan Algoritma Bellman-Ford dapat digunakan pada graf yang mengandung simpul negatif selama graf tidak mengandung kalang negatif yang dapat dicapai dari titik awal.

Penelitian yang lain berjudul Algoritma Bellman-Ford Untuk Menentukan Jalur Tercepat Dalam Sistem Informasi Geografis yang ditulis oleh Rully Pramudita dan Nadya Safitri membahas bagaimana mencari sebuah jalur terpendek berdasarkan kasus yang diambil dari kota Bandung. Penelitian dilakukan untuk mencari jalur terpendek dengan menggunakan Algoritma Bellman-Ford dan metode Direct Comparison approach. Metode ini memiliki 5 


\section{Demitra Januar Bawole, Hanna Prillysca Chernovita}

tahapan yaitu research, verification, unit of comparison, adjustment analysis dan reconciliation (UBC, 2013). Penelitian ini menyimpulkan bahwa perhitungan dari jalan Ir. H. Djuanda menuju Terminal Bis Leuwipanjang menggunakan Algoritma Bellman-Ford menghasilkan rute terpendek, sebesar 10,6 km dengan rute simpul A-Q-P-R (Jl. Ir.H.Djuanda (Cikapayang) - Simpang empat Jl.R.E Martadinata dan Jl. Jend.Ahmad Yani - Simpang tiga Jl.BKR dan Jl.M.Ramdan - Terminal Leuwipanjang).

Secara konseptual, penelitian di atas memiliki persamaan dengan penelitian ini yaitu menentukan jalur terpendek, namun penelitian ini lebih berfokus melakukan penentuan jarak antara satu simpul dengan simpul yang lain serta menghitung jarak yang akan ditempuh atau jalur terpendek dengan menggunakan Algoritma Bellman-Ford dengan studi kasus perusahaan asuransi.

\section{Algoritma Bellman-Ford}

Algoritma ini dikembangkan oleh Richard Bellman and Lester Ford, Jr. Algoritma ini sangat mirip dengan Algortima Dijkstra namun algortima ini mampu menangani bobot negatif pada pencarian jalur terpendek pada sebuah graf berbobot. Algoritma Bellman-Ford merupakan pengembangan dari Algoritma Dijkstra, Algortima Bellman-Ford akan benar jika dan hanya jika graf tidak terdapat cycle dengan bobot negatif yang dicapai dari sumber. Secara umum langkah - langkah algoritmanya adalah sebagai berikut (Cormen, 2009):

1. Tentukan Vertex Source dan daftar seluruh vertices maupun edges.

2. Assign nilai untuk distance dari vertex source $=0$, dan yang lain infinite.

3. Mulailah iterasi terhadap semua vertices yang berhubungan dengan vertex source dengan formula sebagai berikut ini:

- $\quad U=$ Vertex asal

- $\quad \mathrm{V}=$ Vertex Tujuan

- $\quad \mathrm{UV}=$ Edges yang menghubungkan $\mathrm{U}$ dan $\mathrm{V}$

- Jika idistance $\mathrm{V}$, lebih kecil dari distance $U+$ Weigh $U V$ maka idistance $\mathrm{V}$, diisi dengan idistance $\mathrm{U}+$ iweigh $\mathrm{UV}$

- Lakukan hingga semua vertex terjelajahi

\section{Sistem Informasi Geografis}

Menurut Anon (2002) Sistem Informasi Geografi (SIG) adalah suatu sistem informasi yang dapat memadukan antara data grafis (visual) dengan data teks (atribut) objek yang dihubungkan secara geografis di bumi (georeferenced). Arronoff (1989) mengartikan SIG sebagai sistem berbasis komputer yang memiliki kemampuan dalam menangani data bereferensi geografi yaitu pemasukan data, manajemen data (penyimpanan dan pemanggilan kembali), memanipulasi dan analisis data, serta keluaran sebagai hasil akhir (output). Winarto, et.al (1994) mendefinisikan SIG sebagai suatu sistem sistem untuk mendayagunakan dan menghasilgunakan: penyimpanan, pengolahan dan analisis data spasial (keruangan), serta data non spasial (tabular) dalam memperoleh berbagai informasi yang berkaitan dengan aspek keruangan baik berorientasi ilmiah, komersial, pengolahan, maupun kebijakan. Sedangkan Burrough (1986) mendefinisikan Sistem Informasi Geografi sebagai sistem berbasis komputer yang digunakan untuk memasukkan, menyimpan, mengelola, menganalisis, dan mengaktifkan kembali data yang mempunyai referensi keruangan untuk berbagai tujuan yang berkaitan dengan pemetaan dan perencanaan. 


\section{Teori Graph}

Graf (graph) digunakan untuk memrepresentasikan atau memproyeksi objek - objek diskrit dan hubungan antara objek-objek tersebut. Representasi visual dari graf dengan menyatakan objek dinyatakan noktaf, bulatan, atau titik, sedangkan hubungan antara objek dengan objek dinyatakan garis. Sejarah dari graf pada mulanya penggunaan jaringan yang memuat titik dan sisi digunakan oleh matematikawan Swiss, Leonhard Euler (1707- 1783), untuk memecahkan masalah tujuh jembatan Konigsberg. Di kota Prussia, Jerman, sungai Pregel mengalir melewati kota, dan menutupi Pulau Kneiphof. Pulau tersebut dihubungkan oleh dua jembatan ke masing-masing tepi daratan $\mathrm{C}$ dan $\mathrm{B}$, dan tambahan tiga jembatan yang menghubungkan ke sebuah wilayah. Masalah yang ingin diselesaikan adalah "Dapatkah seseorang melewati semua jembatan dengan masing-masing jembatan terlewati tepat satu kali, dan kembali ke tempat semula?". Jaringan dapat direpresentasikan dengan baik melalui graf. Sehingga untuk menyelesaikan masalah jaringan harus mengetahui tentang graf .

\section{Metode Penelitian}

Metode penelitian merupakan langkah-langkah untuk menyelesaikan penelitian, adapun langkah-langkah yang digunakan dalam penelitian ini dapat di lihat di Tabel 1.

\section{Pengumpulan Data (Tahap 1)}

Langkah awal dalam proses penelitian dengan melakukan pengumpulan data berupa studi literatur, data sekunder, pengambilan data koordinat lokasi awal serta akhir dan akhir rute dalam melakukan survey klaim. Dalam tahapan ini juga dilakukan verifikasi data dengan data perusahaan.

Analisis dan perhitungan algoritma (Tahap 2)

Tahap ini dilakukan pembentukan graf yaitu kumpulan-kumpulan dari simpul-simpul yang dihubungkan, setelah itu penentuan jalur terpendek dengan menggunakan Algoritma BellmanFord yang terdiri dalam beberapa tahapan yaitu : fase pertama, menentukan titik 1 sebagai awal dan mendaftar semua sisi; fase kedua, memberi nilai untuk titik awal sama dengan nol dan yang lainnya tak terhingga; fase ketiga melakukan perhitungan algoritma.

Hasil dan Kesimpulan (Tahap 3)

Hasil perhitungan rute yang dihasilkan berupa rute terdekat atau jalur-jalur yang akan dilewati. 


\begin{tabular}{|c|c|c|c|}
\hline Tahap & Masukan & Proses & Keluaran \\
\hline \multirow[t]{4}{*}{1} & Studi Literatur & \multirow[b]{3}{*}{ 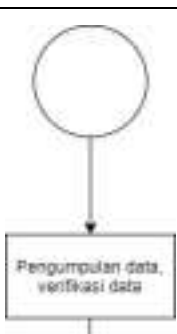 } & $\begin{array}{l}\text { Capture peta dari } \\
\text { Google Maps }\end{array}$ \\
\hline & Data sekunder, data perusahaan & & $\begin{array}{l}\text { Koordinat awal dan } \\
\text { akhir rute perusahaan }\end{array}$ \\
\hline & $\begin{array}{l}\text { Peta yang didapat dari Google } \\
\text { Maps diverifikasi }\end{array}$ & & $\begin{array}{lll}\text { Peta yang } & \text { sudah } \\
\text { diverifikasi } & \text { sesuai }\end{array}$ \\
\hline & $\begin{array}{l}\text { Melakukan verifikasi data dengan } \\
\text { membandingkan data dengan data } \\
\text { perusahaan }\end{array}$ & & dengan data perusahaan \\
\hline 2 & Pembentukan graf & & Graf \\
\hline & $\begin{array}{l}\text { Tahapan masing-masing } \\
\text { algoritma }\end{array}$ & Keamplatan & $\begin{array}{lr}\text { Hasil perhitungan } \\
\text { mengunakan } & \text { tahapan- } \\
\text { tahapan } & \text { algoritma } \\
\text { bellman ford } & \\
\end{array}$ \\
\hline 3 & Hasil Graf & & Kesimpulan \\
\hline & $\begin{array}{l}\text { Hasil Perhitungan menggunakan } \\
\text { tahapan Algoritma Bellman-Ford }\end{array}$ & & \\
\hline
\end{tabular}

Tabel 1. Tahapan Metodelogi Penelitian

\section{Pembahasan}

Salah satu solusi untuk mempermudah dan mempercepat kerja surveyor atau pelaku survey Asuransi Sinar Mas ke masing - masing bengkel rekanan adalah dengan memanfaatkan Algoritma Bellman-Ford dalam menentukan rute atau jalur terpendek sehingga surveyor diharapkan sampai di bengkel tujuan dengan waktu yang singkat. Perhitungan menggunakan Algoritma Bellman-Ford dilakukan dengan memperhitungkan jarak lokasi awal yaitu Kantor Pusat Asuransi Sinar Mas dengan lokasi tujuan yaitu bengkel rekanan Asuransi Sinar Mas yang menjadi lokasi survey.

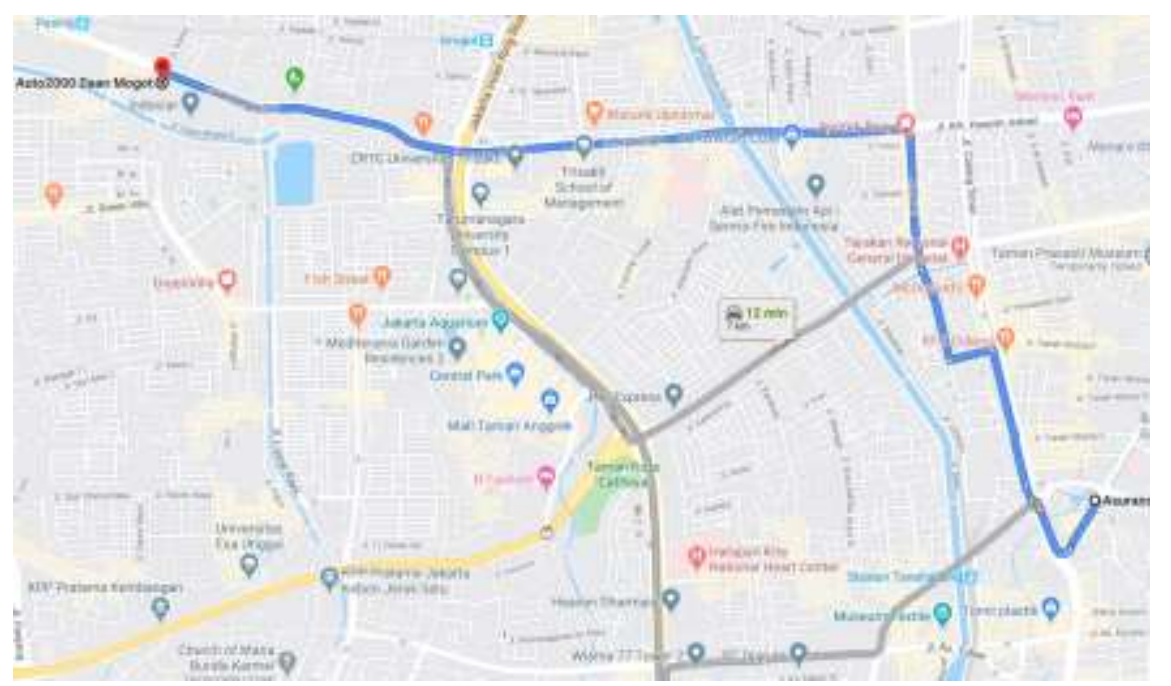

Gambar 2. Rute Asuransi Simas Mobil dengan Auto 2000 Daan Mogot 
Penelitian ini mengambil kasus pada salah satu bengkel rekanan Asuransi Sinar Mas yaitu Auto 2000 Daan Mogot sebagai titik akhir dan kantor pusat Asuransi Sinar Mas sebagai titik awal. Gambar 2 memperlihatkan rute antara kantor pusat Asuransi Sinar Mas Mobil dengan Auto 2000 Daan Mogot yang didapatkan dari Google Maps, kemudian dapat digambarkan titik awal dan titik akhir menggunakan node yang terlihat pada Gambar 3.

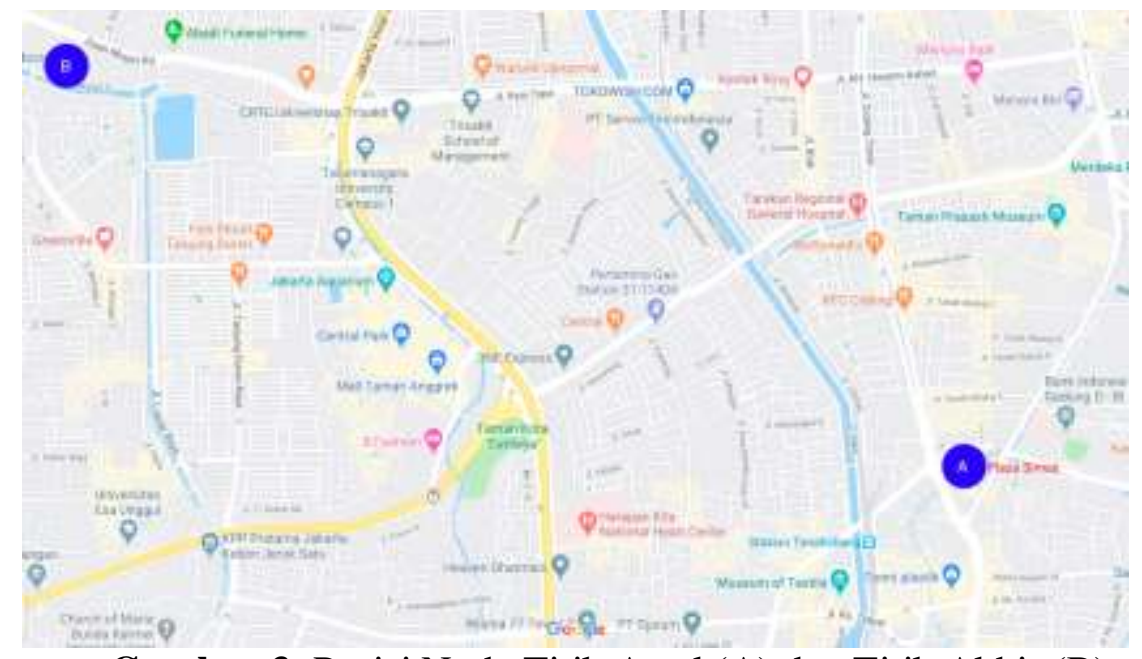

Gambar 3. Posisi Node Titik Awal (A) dan Titik Akhir (B).

Gambar 3 menggambarkan node A sebagai titik awal rute yaitu kantor pusat Asuransi Sinar Mas Mobil dan node B sebagai titik akhir yaitu bengkel Auto 2000 Daan Mogot sebagai bengkel rekanan yang akan dikunjungi oleh surveyor. Dengan data masing - masing rute dari node A menuju node B yang didapatkan dari Google Maps, maka akan diwakilkan menggunakan node - node yang terlihat pada Gambar 4.

Tabel 2. Titik Koordinat Node

\begin{tabular}{|c|c|c|}
\hline Node & X & Y \\
\hline A & -6.183298 & 106.815487 \\
\hline B & -6.163648 & 106.775303 \\
\hline C & -6.175735 & 106.811788 \\
\hline D & -6.176119 & 106.809923 \\
\hline E & -6.171441 & 106.808577 \\
\hline F & -6.165836 & 106.808208 \\
\hline H & -6.166937 & 106.787556 \\
\hline I & -6.189074 & 106.806631 \\
\hline J & -6.189304 & 106.796892 \\
\hline G & -6.179530 & 106.795932 \\
\hline
\end{tabular}


INOBIS: Jurnal Inovasi Bisnis dan Manajemen Indonesia

Volume 03, Nomor 01, Desember 2019

Demitra Januar Bawole, Hanna Prillysca Chernovita

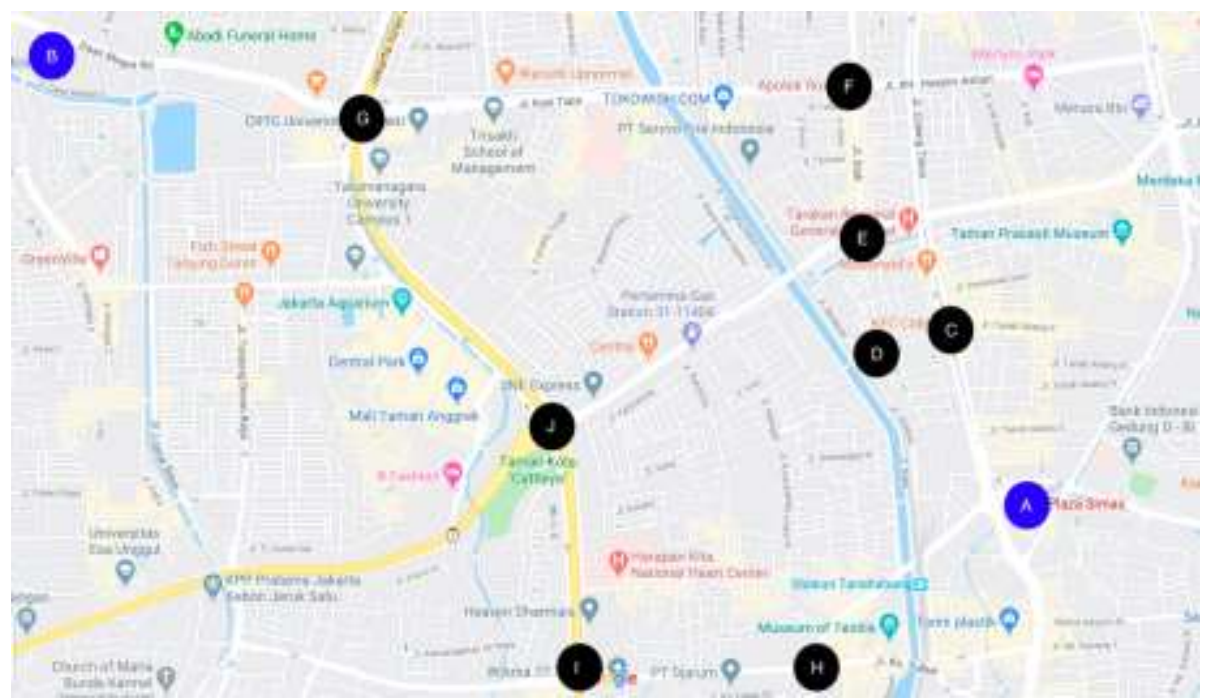

Gambar 4. Node untuk Rute Asuransi Sinarmas menuju Auto 2000 Daan Mogot

Gambar 4 berisikan node-node yang mewakili titik persimpangan dan setiap rute yang dapat dilewati oleh surveyor dari Asuransi Sinarmas menuju Auto 2000 Daan Mogot. Setelah berhasil mendapatkan setiap node, maka masing-masing node akan dihubungkan menggunakan graf seperti Gambar 5.

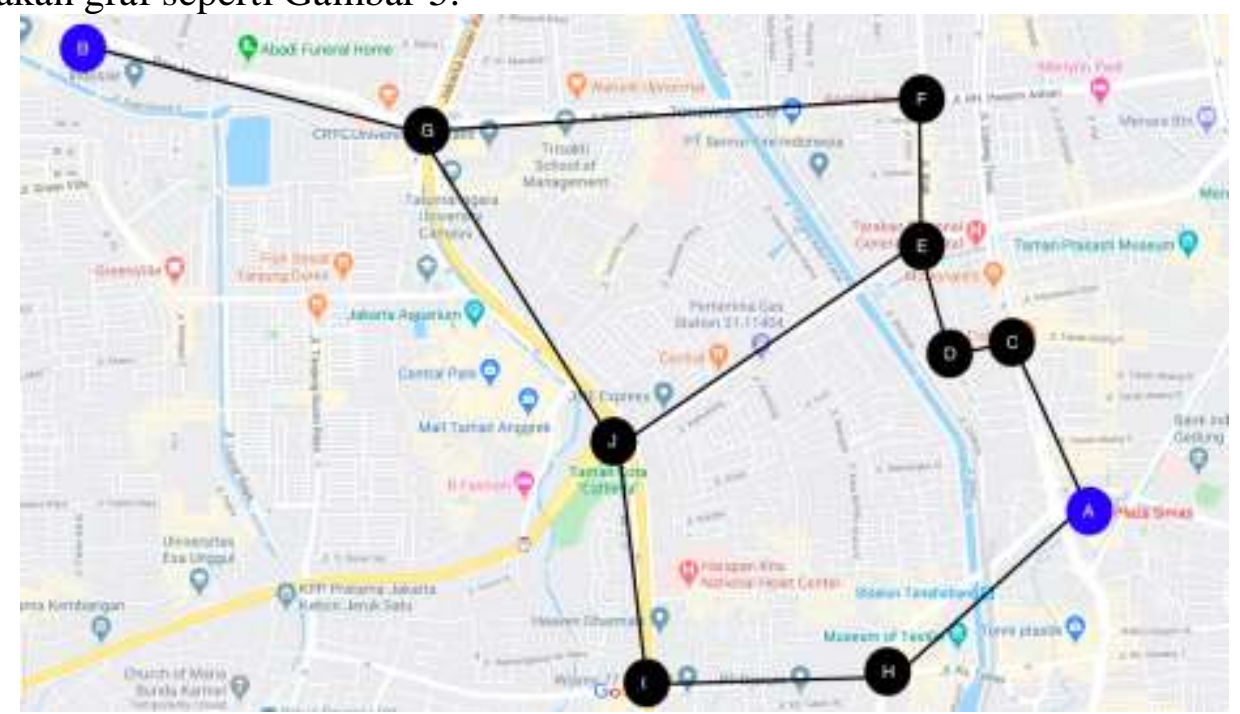

Gambar 5. Node yang terhubung dengan graf di setiap rute dari Asuransi Sinarmas menuju Auto 2000 Daan Mogot

Setelah setiap node saling terhubung menggunakan graf, maka setiap jalur yang terbentuk akan dianalisis jaraknya dan digambarkan kembali berdasarkan node dan graf pada Gambar 6. 
INOBIS: Jurnal Inovasi Bisnis dan Manajemen Indonesia Volume 03, Nomor 01, Desember 2019

\section{Demitra Januar Bawole, Hanna Prillysca Chernovita}

Tabel 3. Rute dan Jalan yang dilalui

\begin{tabular}{|l|l|}
\hline Rute & Nama Jalan \\
\hline $\mathrm{A} \rightarrow \mathrm{C}$ & Jalan Cideng Barat \\
\hline $\mathrm{C} \rightarrow \mathrm{D}$ & Jalan Tanah Abang II \\
\hline $\mathrm{D} \rightarrow \mathrm{E}$ & Jalan Kyai Caringin \\
\hline $\mathrm{E} \rightarrow \mathrm{F}$ & Jalan Biak \\
\hline $\mathrm{A} \rightarrow \mathrm{H}$ & Jalan Jati Baru Raya \\
\hline $\mathrm{H} \rightarrow \mathrm{I}$ & Jalan Slipi \\
\hline $\mathrm{I} \rightarrow \mathrm{J}$ & Jalan Letjen S.Parman \\
\hline $\mathrm{J} \rightarrow \mathrm{G}$ & Jalan Satria \\
\hline $\mathrm{F} \rightarrow \mathrm{G}$ & Jalan Kyai Tapa \\
\hline $\mathrm{G} \rightarrow \mathrm{B}$ & Jalan Daan Mogot \\
\hline
\end{tabular}

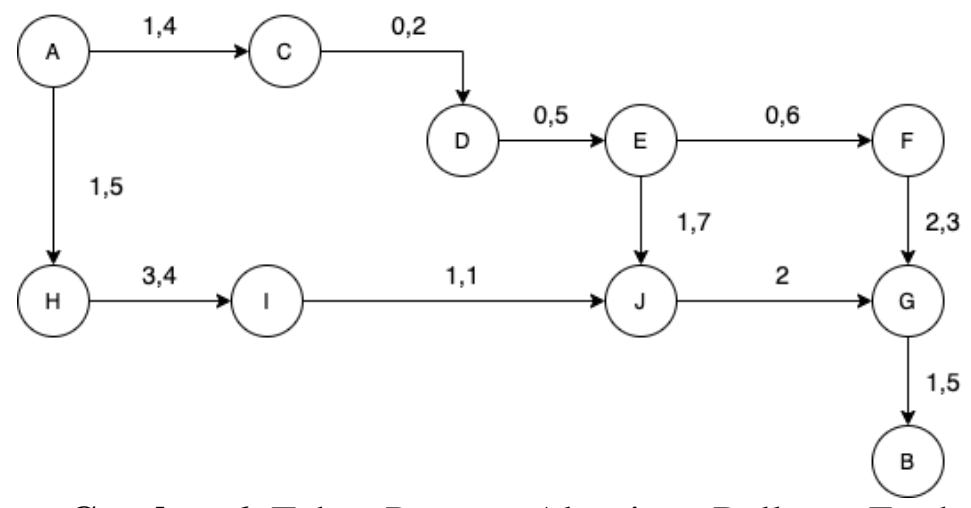

Gambar 6. Tahap Pertama Algoritma Bellman-Ford

Gambar 6 merupakan tahapan awal dalam Algoritma Bellman-Ford yaitu menggambarkan masing-masing node dan graf yang saling terhubung mewakili masingmasing jalur dari titik awal menuju titik tujuan beserta jarak antar node. Gambar 5 didapatkan dengan menerjemahkan rute yang telah dibuat pada Gambar 5 ke dalam inode dan graf sehingga pencarian rute terpendek menggunakan Algoritma Bellman-Ford akan lebih mudah. Adapun langkah-langkah yang dilakukan untuk mencari rute terpendek menggunakan Algoritma Bellman-Ford hingga implementasi pada bahasa pemrograman Python akan dijelaskan seperti dibawah ini.

Adapun langkah-langkah untuk menentukan rute terpendek menggunakan Algoritma Bellman-Ford adalah sebagai berikut.

1. Menentukan titik awal dan mendaftarkan semua semua titik maupun sisi.

2. Memberikan nilai 0 pada titik awal dan nilai tak terhingga pada titik yang lainnya.

3. Memulai iterasi pada setiap titik dengan titik awal sebagai iterasi pertama dengan formula sebagai berikut :

$\mathrm{U}$ : Titik awal

$\mathrm{V}$ : Titik akhir / tujuan

UV : Sisi yang menghubungkan titik awal (U) dengan titik akhir (V).

Apabila jarak V lebih besar dari jarak U + bobot UV maka jarak V diisi dengan jarak $\mathrm{U}+$ bobot UV. Formula ini dilakukan hingga iterasi terakhir yaitu pada saat semua titik berhasil dilewati. 


\section{Demitra Januar Bawole, Hanna Prillysca Chernovita}

4. Melakukan pengecekan apakah ada siklus yang bernilai negatif dalam graf. Dengan formula, apabila jarak V lebih besar dari jarak U + bobot UV maka graf mempunyai siklus yang bernilai negatif.

Pada penjelasan selanjutnya akan berisikan keterangan terhadap langkah - langkah diatas. Langkah pertama telah dijelaskan dan digambarkan melalui Gambar 5 yaitu titik A sebagai titik awal dan terdapat 9 titik/node beserta 10 sisi/graf. Kemudian untuk langkah selanjutnya terdapat pada gambar 6 .

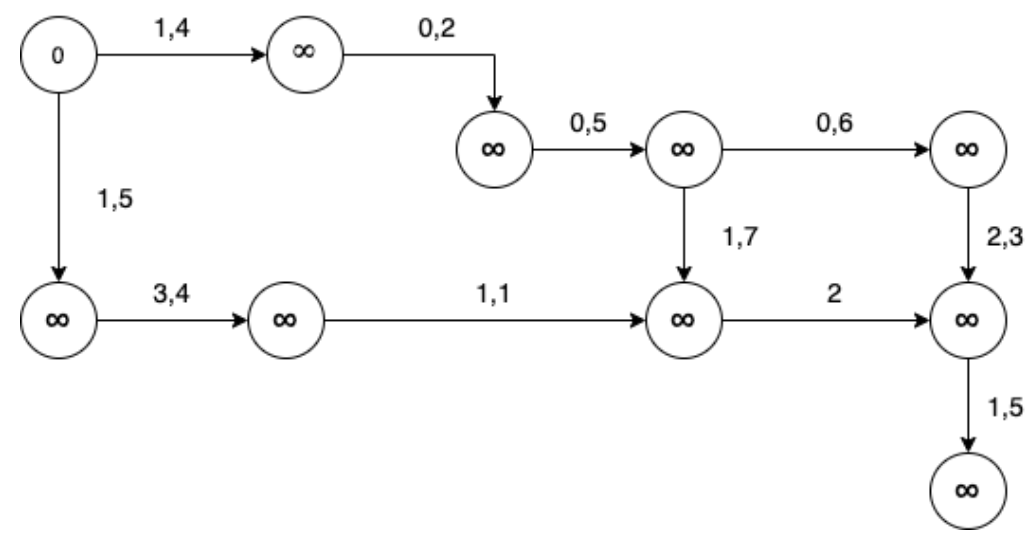

Gambar 7. Tahap Kedua Algoritma Bellman-Ford

Gambar 7. Nilai 0 pada titik awal dan nilai tak terhingga pada titik lainnya Dilanjutkan dengan proses iterasi pada semua titik maupun sisi dengan formula yang telah dijelaskan di poin ketiga dalam langkah-langkah untuk menentukan jalur atau rute terpendek menggunakan Algoritma Bellman-Ford di atas. Berikut iterasi terhadap semua titik yang dilewati:

4.1 Iterasi Pertama :

$$
\begin{aligned}
& \mathrm{A} \rightarrow \mathrm{C}=0+1,4=1,4 \\
& \mathrm{~A} \rightarrow \mathrm{H}=0+1,5=1,5
\end{aligned}
$$

4.2 Iterasi Kedua :

$$
\begin{aligned}
& \mathrm{C} \rightarrow \mathrm{D}=1,4+0,2=1,6 \\
& \mathrm{H} \rightarrow \mathrm{I}=1,5+3,4=4,9
\end{aligned}
$$

4.3 Iterasi Ketiga :

$$
\begin{aligned}
& \mathrm{D} \rightarrow \mathrm{E}=1,6+0,5=2,1 \\
& \mathrm{I} \rightarrow \mathrm{J}=4,9+1,1=6
\end{aligned}
$$

4.4 Iterasi Keempat :

$\mathrm{E} \rightarrow \mathrm{F}=2,1+0,6=2,7$

$\mathrm{E} \rightarrow \mathrm{J}=2,1+1,7=3,8$

4.5 Iterasi Kelima :

$$
\begin{aligned}
& \mathrm{F} \rightarrow \mathrm{G}=2,7+2,3=5 \\
& \mathrm{~J} \rightarrow \mathrm{G}=3,8+2,3=6,1
\end{aligned}
$$

4.6 Iterasi Keenam :

$\mathrm{G} \rightarrow \mathrm{B}=5+1,5=6,5$

Berdasarkan langkah - langkah yang telah diterapkan, maka penjelasan atas proses iterasi adalah sebagai berikut.

1. Iterasi pertama yaitu poin 4.1 yang merupakan iterasi dari titik A sebagai titik awal ke titik $\mathrm{C}$ dan titik A ke titik $\mathrm{H}$. Pada iterasi pertama titik $\mathrm{C}$ diisi dengan jarak titik A ke titik $\mathrm{C}$ dengan jarak minimum dari titik A ke titik $\mathrm{C}$ yaitu $0+1,4=1,4 \mathrm{~km}$. Dan untuk titik $\mathrm{H}$ diisi dengan jarak titik A ke titik $\mathrm{H}$ yaitu $0+1,5=1,5 \mathrm{~km}$. 


\section{Demitra Januar Bawole, Hanna Prillysca Chernovita}

2. Iterasi kedua yaitu poin 4.2 yang merupakan iterasi dari titik $\mathrm{C}$ ke titik $\mathrm{D}$ dan titik $\mathrm{H}$ ke titik I. Pada iterasi kedua titik D diisi dengan jarak titik C ke titik D sejauh 1,6, sedangkan untuk titik I diisi dengan jarak titik $\mathrm{H}$ ke titik I sejauh 4,9 km.

3. Iterasi ketiga yaitu poin 4.3 yang merupakan iterasi dari titik D ke titik $E$ dan titik I ke titik J. Dengan total masing - masing jarak tersebut secara berurutan adalah 2,1 km dan $6 \mathrm{~km}$.

4. Iterasi keempat yaitu poin 4.4 yang merupakan iterasi dari titik $\mathrm{E}$ ke titik $\mathrm{F}$ dan titik $\mathrm{E}$ ke titik J. Dengan total masing - masing jarak tersebut secara berurutan adalah 2,7 km dan $3,8 \mathrm{~km}$.

5. Iterasi kelima yaitu poin 4.5 yang merupakan iterasi dari titik $F$ ke titik $G$ dan titik $\mathbf{J}$ ke titik G. Dengan total masing - masing jarak tersebut secara berurutan yaitu $5 \mathrm{~km}$ dan $6,1 \mathrm{~km}$.

6. Iterasi keenam yaitu poin 4.6 yang merupakan iterasi dari titik $G$ ke B sebagai jarak terhadap titik terakhir yaitu $6,5 \mathrm{~km}$.

Pada iterasi kelima semua titik maupun sisi telah terlewati dan terdapat 2 jalur dengan masing - masing total jarak yaitu $5 \mathrm{~km}$ dan 6,1 km sehingga pada iterasi ke-enam merupakan total jarak minimum yang dapat dicapai oleh proses iterasi. Berikut adalah hasil rute terpendek yang dihasilkan oleh Algoritma Bellman-Ford.

a) Pada iterasi pertama terdapat 2 rute yang tersedia sehingga dari 2 rute tersebut yang merupakan rute minimum adalah $\mathbf{A}-\mathbf{C}$ dengan jarak $1,4 \mathrm{~km}$.

b) Pada iterasi kedua juga terdapat 2 rute yang merupakan lanjutan dari iterasi pertama sehingga rute minimumnya adalah A-C-D dengan jarak $1,6 \mathrm{~km}$.

c) Pada iterasi ketiga terdapat 2 rute lanjutan sehingga rute dengan jarak minimum adalah rute A-C-D-E dengan jarak $2,1 \mathrm{~km}$.

d) Rute selanjutnya yang merupakan rute minimum yang berhasil dibentuk adalah rute AC-D-E-F dengan total jarak $2,7 \mathrm{~km}$.

e) Iterasi selanjutnya terdapat pilihan 2 rute yang dihasilkan dari rute sebelumnya dan rute dengan jarak minimum adalah A-C-D-E-F-G dengan jarak 5 km.

Iterasi terakhir yang menghasilkan rute tunggal yang berarti semua titik berhasil dilewati namun hanya menghasilkan satu rute minimum yaitu A-C-D-E-F-G-B dengan total jarak 6,5 km sebagai jarak rute terpendek.

\section{Kesimpulan}

Penentuan titik awal dari Kantor Pusat Sinar Mas (Jalan Fachrudin) dengan menggunakan Algoritma Bellman-Ford menghasilkan rute terpendek sebesar, 6,5 km dengan rute simpul A-C-D-E-F-G-B (Jalan Cideng Barat - Jalan Tanah Abang II - Jalan Kyai Caringin - Jalan Biak - Jalan Kyai Tapa - Jalan Daan Mogot ). Algoritma Bellman-Ford digunakan untuk mengetahui lintasan minimum yang akan ditempuh dalam pencarian rute terpendek sehingga mempermudah surveyor mengetahui lintasan yang akan ditempuh serta jarak terdekat yang akan dilalui. Penelitian seperti ini dapat menjadi inputan bagi perusahaan asuransi atau perusahaan yang memiliki mobilitas di jalan yang tinggi sehingga mempermudah dalam pencarian rute terdekat. 


\section{Daftar Pustaka}

Anang Widhi Nirwansyah, S.Pd., M.Sc , Dasar Sistem Informasi Geografis dan Aplikasi Menggunakan ARCGIS 9.3, Yogyakarta : Deepublish

Agustian Aji P, Sholeh Hadi Pramono, M. Aziz Muslim .2015. Optimasi Jalur Tercepat Dengan Menggunakan Modifikasi Algoritma Bellman Ford (Studi Kasus Lintasan antar kecamatan Kota Malang), Jurnal EECCIS Vol 9 No 2

Fenny Anggraini, Sugeng Mingparwoto, 2014, Penerapan Metode Algoritma Bellman-Ford dalam Aplikasi Pencarian Perseroan Terbatas di PT. Jakarta Industrial Estate Pulogadung (PT.JIEP), Jurnal Teknologi , Vol 7 No 1

Paska Marto Hasugian , 2015, Analisa dan Implementasi Algoritma Bellman Ford dalam Menentukan Jalur Terpendek Pengantaran barang dalam Kota, Jurnal Mantik Penusa vol. 18 , no. 2 , pp. $118-123$,.

Reynaldi, Reynaldi , 2018, Rancang bangun aplikasi pencarian rute angkutan umum jakarta menggunakan Algoritma Bellman-Ford, Bachelor Thesis, Universitas Multimedia Nusantara.

Rully Pramudita , Nadya Safitri , 2018 , Algoritma Bellman-Ford Untuk Menentukan Jalur Tercepat Dalam Sistem Informasi Geografis, Jurnal Penelitian Ilmu Komputer, System Embedded \& Logic Vol :6(2) : 105-114

Saeful Hamdi, Prihandoko , 2018 , Analsis Algoritma Dijktra dan Algoritma Bellman-Ford Sebagai Penentuan Jalur Terpendek Menuju Lokasi Kebakaran (Studi Kasus : Kecamatan Praya Kota), E- Journal UPM. Vol 8 No 1.

UNDANG-UNDANG REPUBLIK INDONESIA No 2 Tahun 1992 Tentang Usaha Pengasurasian 